\title{
Can Macroinvertebrate Assemblage Changes Be Used as Biological Indicator of Water Quality of the Nokoue Lake (Benin)?
}

\author{
Hamed Odountan*, Youssouf Abou \\ Research Unit on Wetlands, Department of Zoology, Faculty of Sciences and Technics, University of \\ Abomey-Calavi, Abomey-Calavi, Benin \\ Email: "oolahamo@gmail.com
}

Received 19 November 2015; accepted 21 December 2015; published 24 December 2015

Copyright (C) 2015 by authors and Scientific Research Publishing Inc.

This work is licensed under the Creative Commons Attribution International License (CC BY).

http://creativecommons.org/licenses/by/4.0/

(c) (i) Open Access

\begin{abstract}
Investigations on biological capacity of water quality of macroinvertebrate community are very uncommon, and such as the amount of information available on the Nokoue Lake (the largest lake of Benin) is very limited. This information gap needs to be filled for better management of the Nokoue Lake. The goal of this study was to evaluate the possibility of using the macroinvertebrate community structures in Nokoue Lake and the environmental factors responsible for the maintenance of these structures. Nokoue Lake was studied over three months, during high flood period in which time subsurface water and macroinvertebrate samples were collected and analyzed. A study showed that the macroinvertebrate assemblages was done according to ecological gradients as $\mathrm{pH}$, conductivity, TDS, salinity, chlorophyll a and probably to anthropogenic actions (nutriments). Better than the percentage of insects, the percentage of Chironomidae informed very well about macroinvertebrate assemblages. To assess the biological health of the environment, the Family Biotic Index (FBI) turns out to be more appropriate than diversity indices that do not take into account the intermediate pollution. Organic pollution revealed by the FBI probably affects the aquatic life.
\end{abstract}

\section{Keywords}

Nokoue Lake, Macroinvertebrates, Family Biotic Index, Flood Period, Diversity Indices

"Corresponding author.

How to cite this paper: Odountan, H. and Abou, Y. (2015) Can Macroinvertebrate Assemblage Changes Be Used as Biological Indicator of Water Quality of the Nokoue Lake (Benin)? Journal of Environmental Protection, 6, 1402-1416. 


\section{Introduction}

The rapid increase of population in developing countries has increased the level of anthropogenic impact. This is illustrated by bad agricultural practices, changing land uses, the extent of eroded surfaces and discharges of unprocessed waste water [1] [2]. This, coupled with climate change, leads to deterioration in the quality of coastal and inland surface water as lakes, ultimate natural receptor [2] [3]. This anthropogenic pollution leads to e.g. eutrophication of exposed lakes which is characterized by the proliferation of invasives such as Eichhornia crassipes [4] [5], generally most pronounced near built up human areas [6].

The lagoon complex Nokoue Lake-Porto-Novo lagoon (RAMSAR site 1018), is the largest continental lake in Benin, in view of its extent, productivity and exploitation [7]. Moreover, Nokoue Lake is the most productive lagoon of West Africa [8] [9]. The intensification of exploitation of natural resources by local people leads to an alarming acceleration of environmental degradation processes and poses a risk of fish stock depletion. Changes in trophic status and fluctuations in the volume of water add to the complexity of environmental changes [5] [8] [10]. The ecological integrity of the lake is threatened.

For a better management of aquatic ecosystems, biological monitoring of their ecological state is needed because biological indicators have great power of information integration. Indeed, even if it cannot fully replace physicochemical indicators, biological monitoring has advantage to measure the capacity of the ecosystem to maintain its functional balance [11] [12]. Prime examples of this are the detection of pollutants and degradation of aquatic and riparian habitats [13]. Benthic macroinvertebrates are one of the most used groups of organisms today as biological indicators [14] [15]. These benthic organisms are endowed with continuous integration capacity of their environmental conditions and have many advantages such as ubiquity, settled way of life, high number of species and the relatively long life cycle [15]. A policy of sustainable development and protection of aquatic ecosystems may fail if during its development and its implementation there is a lack of information on the variability of the macrobenthic fauna for assessing the actual impact of pollution and alteration of aquatic and riparian habitats [15] [16].

Despite the work already done on macroinvertebrates ecology in Benin [7] [17]-[19], the importance of benthos remains little known. These works are essentially based on diversity metrics without biological indicators aspects. Moreover, previous results need to be updated in order to be more efficient in its management. This paper aimed at providing temporal information on the environmental characteristics and macroinvertebrate assemblages as biological indicators of Nokoue Lake during high flood period.

\section{Materials and Methods}

\subsection{Study Area}

Nokoue Lake (Figure 1), South Eastern Benin $\left(6^{\circ} 25^{\prime} \mathrm{N}, 2^{\circ} 36^{\prime} \mathrm{E}\right)$ is shallow (mean depth $1.5 \mathrm{~m}$, maximum depth of $8 \mathrm{~m}$ ), occupies an area of approximately $150 \mathrm{~km}^{2}$ in dry periods and is the largest brackish water area of Benin [8]. It has an average length of $20 \mathrm{~km}$ (East-West) and a width of $11 \mathrm{~km}$ (North-South). It communicates to the east with Porto-Novo lagoon $\left(35 \mathrm{~km}^{2}\right)$. The lake is directly connected to the Atlantic Ocean by the Cotonou channel (length of $4.5 \mathrm{~km}$ and about $300 \mathrm{~m}$ wide). There is a strong saline intrusion in the dry season. The $\mathrm{pH}$ varies little between the bottom and the surface of the lake. It averages between 6.6 and 7.5 for bottom water and between 6.9 and 7.8 and for surface water [20]. The dissolved oxygen is very variable in time and space (down to $0.5 \mathrm{mg} \cdot \mathrm{L}^{-1}$ in areas of high pollution but reaches $9.0 \mathrm{mg} \cdot \mathrm{L}^{-1}$ in areas close to the sea). Mean annual temperature is $27^{\circ} \mathrm{C}$ [7] [20] [21].

From a climate and hydrological viewpoint, the lake is subject to a sub-equatorial climate characterized by an alternation of two rainy seasons and two dry seasons of unequal durations. Its water regime is characterized by low flood situations (May-June), high flood (September to November) and a dry period (December to March) because of the local climate and the main tributaries which are: Oueme (watershed 46,500 km² and $523 \mathrm{~km}$ length), the Sô (1000 km² drainage basin and length $70 \mathrm{~km}$ ) and the channel of Cotonou (tributary of seawater length $4.5 \mathrm{~km}, 300 \mathrm{~m}$ width) [5] [7].

According to [7], the flora of lake Nokoué is classified into two groups: species typical for periodically flooded areas and species of non-flooded areas. Among the periodically flooded plants, the case of Eichhornia crassipes is of most concern. The aquatic fauna is dominated by shellfish (oysters, marine borers), crustaceans and fish. The fish fauna includes both marine and freshwater species, as well as lagoon species. 


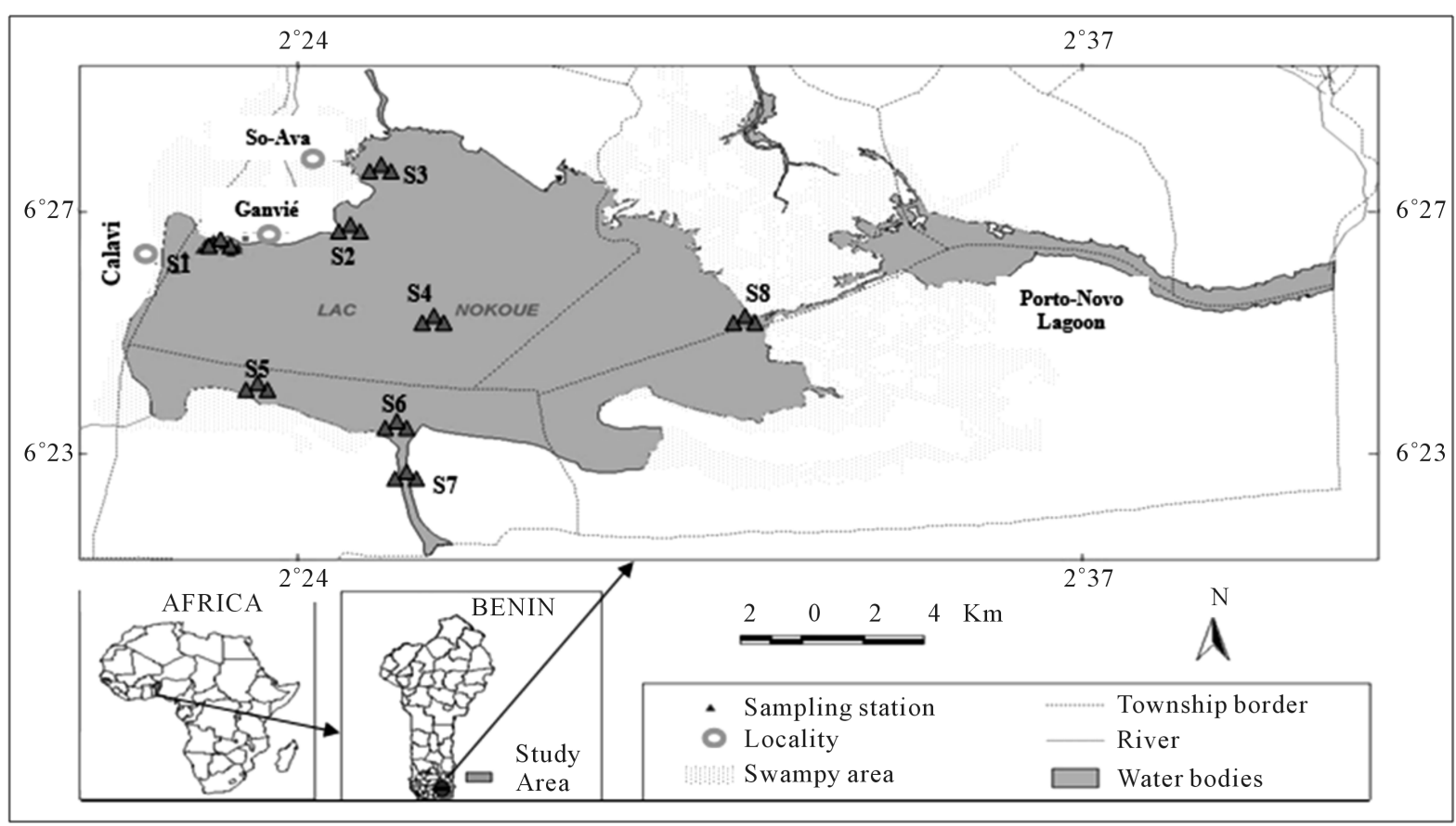

Figure 1. Map of location of the eight sampling stations, Nokoue Lake, Western Benin.

The use of fish traps "acadjas", consisting of an outer ring with hardwood or bamboo poles, inside which soft, brushwood branches 2 - $2.5 \mathrm{~m}$ in length are often placed in a variety of patterns on the muddy bottoms in waters up to $1.5 \mathrm{~m}$ deep [22], contribute to the filling up of the lake [5]. In addition to "acadjas" system, agriculture, trade, fishing, dumping of waste (industrial, home of the local population) and recently sand dredging activities observed on the shores are the mains human activities that affecting the functioning of the lake.

Based on the previous work of [7] [10], 8 stations each consisting of 3 sub-stations were defined by considering salinity, human activities, the extent of the lake and the study global objective. They are: Ganvié (S1), SoZounko (S2), Veki (S3), Middle 1 (S4), Zogbo (S5), Middle 2 (S6), Channel (S7) and Aguégué (S8). These points are shown in Figure 1. Geographic coordinates and some characteristics of the different stations are listed in Table 1. The qualifiers such as "intermediate", "high" and "disturbance" are elements of comparison to explain the differences between stations. Intermediate salinity means $<2 \%$ o whereas high salinity means $>2 \%$.

\subsection{Sampling Design}

Three monthly samples were carried out respectively in September, October and November 2014, covering part of the high flood period using the Qualitative Multi-Habitat (QMH) approach, which provides an exhaustive list of invertebrate taxa present at the various habitats in the sampled area within a specified time, generally less than one hour [23] [24]. It is recommended for fine substrate environments, deepest (e.g. lake) with the presence of macrophytes at some stations [25].

\subsection{Physical and Chemical Characteristics of Water}

On each sampling occasion, physical and chemical variables of water were measured in situ before macroinvertebrates were sampled, between 7 am and 9 am to avoid changes associated with sunshine and photoperiod. The physical variables include transparency and depth measured with a Secchi disk. Chemical variables such as salinity, conductivity, temperature, Total Dissolved Solids (TDS) were measured with a multi-parameter digital meter WTW Cond 3210 SET 1 (Germany) while the pH was measured using a WTW pH multi-parameter digital meter 3110 SET 1 (Germany). The dissolved oxygen was measured with an YSI field Oximeter Model 550 (USA). After the measurement of physical and chemical variables, a water sample of 1.5 liters was collected in a pre-rinsed plastic pot at each substation for laboratory dosing of nutrients and Chlorophyll a. The main nutrients 
Table 1. Sampling stations of Nokoue Lake, with details of station characteristics and human impacts [7] [10].

\begin{tabular}{|c|c|}
\hline Sampling station & Station description and land use \\
\hline $\mathrm{S} 1: 06^{\circ} 25^{\prime} 45^{\prime \prime} \mathrm{N}, 02^{\circ} 23^{\prime} 12^{\prime \prime} \mathrm{E}$ & Intermediate salinity (<2\%), touristic village and strong human pressure \\
\hline S2: $06^{\circ} 27^{\prime} 48^{\prime \prime N}, 02^{\circ} 24^{\prime} 28^{\prime \prime E}$ & Intermediate salinity, near the Sô river and strong human pressure \\
\hline $\mathrm{S} 3: 06^{\circ} 28^{\prime} 24^{\prime \prime} \mathrm{N}, 02^{\circ} 25^{\prime} 02^{\prime \prime} \mathrm{E}$ & Intermediate salinity and very disturbed station \\
\hline $\mathrm{S} 4: 06^{\circ} 26^{\prime} 41^{\prime \prime} \mathrm{N}, 02^{\circ} 25^{\prime} 16^{\prime \prime} \mathrm{E}$ & Intermediate salinity, water current, centered and disrupted \\
\hline S5: $06^{\circ} 24^{\prime} 57^{\prime \prime N}, 02^{\circ} 23^{\prime} 02^{\prime \prime E}$ & High salinity; near the outlet of wastewater and storm water of Cotonou and agglomerations; non dredged \\
\hline S6: $06^{\circ} 24 ' 57^{\prime \prime N}, 02^{\circ} 25^{\prime} 28^{\prime \prime E}$ & High salinity, the lake-channel interface, and very disturbed \\
\hline $\mathrm{S} 7: 06^{\circ} 20^{\prime} 51^{\prime \prime} \mathrm{N}, 02^{\circ} 26^{\prime} 14^{\prime \prime E}$ & Little open Station, near the Atlantic Ocean and high salinity, dredged and very disturbed \\
\hline S8: $06^{\circ} 35^{\prime} 56^{\prime \prime} \mathrm{N}, 02^{\circ} 34^{\prime} 42^{\prime \prime E}$ & Station with very low salinity, mouth of Porto-Novo lagoon and Oueme river, and average human pressure \\
\hline
\end{tabular}

measured were: total phosphorus, orthophosphate, ammonium, nitrite, nitrate and Kjeldahl nitrogen using techniques of molecular absorption spectrophotometric analyses. For nitrite, nitrate, ammonium, total phosphorus and orthophosphates, appropriate relative amounts of appropriate reagents, were used, the sulfonamide 4-aminobenzene, sodium salicylate, Nessler reagent, heptamolybdate, ammonium molybdate and ascorbic acid respectively [26]. The Kjeldahl nitrogen is obtained after a pre-mineralization of the organic material in an acid medium and then is carried by titrimetric assay after addition of a sodium hydroxide solution (organic $\mathrm{NK}=\mathrm{N}+\mathrm{N}^{-} \mathrm{NH}_{4}^{+}$). After the water filtration on Whatman GFA $(0.7 \mu \mathrm{m}$ porosity), the concentration of Chlorophyll a (Chl a) in $\mathrm{g} \cdot \mathrm{L}^{-1}$ of sample is obtained by the method of [27] as described by [26] with the equation:

$$
\text { Chl-a }=27 \times[(\text { Ao665 }- \text { Ao750 })-(\text { Aa665 }- \text { Aa750 })] \times v / L \times V
$$

where: Ao represents the absorbance before the acidification and Aa after acidification; $v$ the volume of acetone used; $\mathrm{L}$ the optical path and $\mathrm{V}$ the volume of water filtered.

\subsection{Macroinvertebrate Samples}

A kick net (mesh size $0.5 \mathrm{~mm}$ ) with a $25 \mathrm{~cm}$ diameter opening, mounted on a steel shaft of $3 \mathrm{~m}$ was used along a transect of $5 \mathrm{~m}$. In addition, samples of 8 root systems of Eichhornia crassipes per substations were also made because of its abundance in quiet areas and the density of its root system which can be a favorable habitat for macroinvertebrates [28] [29]. The samples obtained on a same substation from the two methods were washed and sieved (mesh size $0.2 \mathrm{~mm}$ ) in the water of the lake and the retained materiel was bottled and preserved in 5\% formalin. In the laboratory, the samples were rinsed again thoroughly with clean water on a series of sieves of decreasing mesh $(2 \mathrm{~mm}, 1 \mathrm{~mm}, 0.5 \mathrm{~mm}$ and $0.2 \mathrm{~mm})$ and the organisms were then separated according to their taxonomic group and preserved with $70 \%$ absolute ethanol for identification. Macroinvertebrates were identified to the lowest practicable and possible taxonomic level, mostly genus, according to [30]-[37] and consulting specialists.

The macroinvertebrate assemblage composition was determined for each sampling station and sampling occasion using number of taxa, total number of individuals, and relative abundance of each taxon. The percentage of Ephemeroptera + Plecoptera + Trichoptera (EPT) and the percentage of the various zoological orders and groups like Chironomidae and Oligochaeta was calculated. The Family Biotic Index (FBI) [38] was used to assess the ecological integrity of the habitats:

$$
\mathrm{FBI}=\sum n i \cdot t_{i} / n i
$$

in which $n_{i}$ is the number of individuals in the ith family, $t_{i}$ is the tolerance score of the $i$ th family, and $N$ is the sum of individual numbers in all the families making up the sample.

The higher the score is, the more the habitat is likely to be affected by stress. An FBI value between 0 and 3.75 indicates very good water quality (no organic pollution), 3.76 - 4.25 indicates good water quality (possible slight organic pollution), 4.26 - 5.00 indicates moderate water quality (some organic pollution), 5.01 - 5.75 indicates poor water quality (fairly substantial organic pollution), 5.76 - 6.50 indicates fairly poor water quality: 
(substantial organic pollution likely), 6.51 to 7.25 very poor water quality (very substantial organic pollution), 7.26 - 10.00 very bad water quality (severe organic pollution) [38].

\subsection{Statistical Analysis}

All data analysis was done using SPSS for Windows (IBM SPSS Statistics 20) except the Factorial Correspondence Analysis (FCA) and normality test where Minitab (16 Fr) was used. For all inference tests, 95\% confidence level were accepted to verify all significant differences.

Normality of data was verified using the Ryan-Joiner test while Levenne test was used to verify the homogeneity of variances. The results of these tests were used to make the choice between parametric tests and nonparametric tests. Thus, One-way Analysis of Variance was used in combination with post hoc multiple comparison tests (Tukey and Tamhane) for the comparison of means of different physicochemical variables and biological variables obtained between the stations sampled. The factor considered was either the station or sampling occasions. Furthermore, FCA described the correlation between the abundance of different macroinverte-brate families harvested and the study station considered. The FCA was run after log-transformation of macro-invertebrate species abundance [39]. Abbreviation of all taxa family are listed in Table 2. Pairwise Spearman's rank correlation analysis was performed to investigate the relationship between the studied environmental factors and biological data [29] [40].

Table 2. List of family abbreviation code.

\begin{tabular}{|c|c|c|c|}
\hline Abbreviation & Family & Abbreviation & Family \\
\hline Aesh: & Aeshnidae & Hydr: & Hydrophilidae \\
\hline Amp: & Amphilochidae & Lep: & Leptophlebiidae \\
\hline Aor: & Aoridae & Les: & Lestidae \\
\hline Bae: & Baetidae & Lib: & Libellulidae \\
\hline Belos: & Belostomatidae & Myt: & Mytilidae \\
\hline Bithy: & Bithynidae & Naid: & Naididae \\
\hline Cae: & Caenidae & Nau: & Naucoridae \\
\hline Calo: & Calopterygidae & Nep: & Nepidae \\
\hline Cer: & Ceratoporinidae & Nere: & Nereidae \\
\hline Chir: & Chironomidae & Ostr: & Ostreidae \\
\hline Cir: & Cirolanidae & Pen: & Peneaeidae \\
\hline Coe: & Coenagrionidae & Pho: & Photidae \\
\hline Corb: & Corbulidae & Pisau: & Pisauridae \\
\hline Cord: & Corduliidae & Plan: & Planorbidae \\
\hline Cori: & Corixidae & Pléi: & Pléidae \\
\hline Cul: & Culicidae & Por: & Portunidae \\
\hline Dix: & Dixidae & Pota: & Potamididae \\
\hline Dre: & Dreisseinidae & Pyr: & Pyralidae \\
\hline Dry: & Dryopidae & Ser: & Serpulidae \\
\hline Dyt: & Dytiscidae & Sph: & Sphaeromatidae \\
\hline Gam: & Gammaridae & Sta: & Staphylinoidae \\
\hline Grap: & Grapsidae & Tab: & Tabanidae \\
\hline Hal: & Haliplidae & Tub: & Tubificidae \\
\hline Hept: & Heptagenidae & Xan: & Xantidae \\
\hline Hyd: & Hydraenidae & & \\
\hline
\end{tabular}




\section{Results}

\subsection{Water Quality}

\subsubsection{Temporal and Spatial Patterns}

The temporal and spatial variation of the physicochemical variables are presented in Table 3 and Table 4, respectively. The water depth, temperature, transparency, conductivity and TDS of Nokoue Lake showed significant variation in both space and time $(\mathrm{p}<0.05)$ while $\mathrm{pH}$, dissolved oxygen, $\mathrm{PO}_{4}^{3-}, \mathrm{NH}_{4}^{+}, \mathrm{NO}_{3}^{-}, \mathrm{NO}_{2}^{-}$and salinity showed significant variation only with respect to space. Salinity reveals two very distinct groups: 1 ) Stations 1, 2, 3, 4 and 8 (close to $0 \%$ ) and 2) Stations 5, 6 and 7 which have the higher salinity value with minimum and maximum obtained respectively in October and November for these four stations. Both groups were also observed for conductivity and TDS with the same trend. Chlorophyll a concentrations are lower on average at Station 6 but higher at Station 1. Generally, the chlorophyll a concentration was higher in September but decreases in October and increases again in November (Figure 2). It varied from $32 \mu \mathrm{g} \cdot \mathrm{L}^{-1}$ (S6, October) to $113 \mu \mathrm{g} \cdot \mathrm{L}^{-1}$ (S1, September).

Table 3. Comparison between sampling periods of the physicochemical variables of water measure.

\begin{tabular}{|c|c|c|c|c|}
\hline Variables & September & October & November & Sig \\
\hline Depth (m) & $1.47^{\mathbf{b}} \pm 0.34$ & $1.72^{\mathbf{b}} \pm 0.49$ & $1.16^{\mathrm{a}} \pm 0.48$ & $* * *$ \\
\hline Temperature $\left({ }^{\circ} \mathrm{C}\right)$ & $29.35^{\mathrm{a}} \pm 1.09$ & $29.66^{\mathrm{a}} \pm 1.07$ & $30.44^{\mathbf{b}} \pm 0.94$ & $* * *$ \\
\hline Transparency (m) & $0.32^{\mathrm{a}} \pm 0.08$ & $0.63^{\mathbf{b}} \pm 0.27$ & $0.37^{\mathrm{a}} \pm 0.11$ & $* * *$ \\
\hline Dissolved oxygen (mg. $\mathrm{L}^{-1}$ ) & $1.08^{\mathrm{a}} \pm 0.09$ & $3.92^{\mathbf{b}} \pm 1.07$ & $3.44^{\mathrm{b}} \pm 1.02$ & $* * *$ \\
\hline $\mathrm{pH}$ & $7.08^{\mathbf{b}} \pm 0.51$ & $6.62^{\mathrm{a}} \pm 0.75$ & $7.12^{\mathbf{b}} \pm 0.5$ & $*$ \\
\hline Salinity (\%) & $0.26^{\mathbf{a}} \pm 0.39$ & $0.11^{\mathrm{a}} \pm 0.14$ & $1.85^{\mathrm{a}} \pm 2.61$ & NS \\
\hline Conductivity $\left(\mu \mathrm{S} \cdot \mathrm{cm}^{-1}\right)$ & $591^{\mathrm{a}} \pm 722$ & $319^{\mathrm{a}} \pm 305$ & $3761^{b} \pm 4529$ & $* * *$ \\
\hline $\operatorname{TDS}\left(\mu \mathrm{g} \cdot \mathrm{L}^{-1}\right)$ & $600^{\mathrm{a}} \pm 729$ & $317^{\mathrm{a}} \pm 302$ & $3828^{b} \pm 4582$ & $* * *$ \\
\hline $\mathrm{PO}_{4}^{3-} \quad\left(\mu \mathrm{g} \cdot \mathrm{L}^{-1}\right)$ & $465^{b} \pm 347$ & $9^{\mathrm{a}} \pm 4$ & $9^{a} \pm 6$ & $* * *$ \\
\hline $\mathrm{NH}_{4}^{+}\left(\mu \mathrm{g} \cdot \mathrm{L}^{-1}\right)$ & $237^{\mathrm{a}} \pm 171$ & $327^{\mathrm{a}} \pm 42$ & $482^{b} \pm 170$ & $* * *$ \\
\hline $\mathrm{NO}_{3}^{-}\left(\mu \mathrm{g} \cdot \mathrm{L}^{-1}\right)$ & $25^{\mathbf{a}} \pm 17$ & $68^{\mathbf{b}} \pm 78$ & $69^{b} \pm 53$ & * \\
\hline $\mathrm{NO}_{2}^{-}\left(\mu \mathrm{g} \cdot \mathrm{L}^{-1}\right)$ & $6^{a} \pm 6$ & $35^{\mathrm{a}} \pm 17$ & $83^{b} \pm 96$ & *** \\
\hline
\end{tabular}

${ }^{a, b}$ In each line, means with the same letters as superscripts are not significantly different $(p>0.05) ; N S(p>0.05){ }^{*}(p<0.05){ }^{* *}(p<0.01){ }^{* * *}(p<0.001)$; after $(p>$ $0.05)$.

Table 4. Comparison of physicochemical characteristics of water at different sampling sites in Nokoue Lake. Mean \pm Standard Deviation. Sig = significance. The sampling sites are represented in Figure 1 and described in Table 1.

\begin{tabular}{|c|c|c|c|c|c|c|c|c|c|}
\hline \multirow{2}{*}{ Variable } & \multicolumn{8}{|c|}{ Station } & \multirow{2}{*}{ Sig } \\
\hline & $\mathrm{S} 1$ & $\mathrm{~S} 2$ & S3 & S4 & S5 & S6 & S7 & S8 & \\
\hline $\begin{array}{c}\text { Transparency } \\
\text { (m) }\end{array}$ & $0.62^{\mathbf{b}} \pm 0.29$ & $0.54^{\mathrm{ab}} \pm 0.36$ & $0.4^{\mathrm{ab}} \pm 0.16$ & $0.47^{\mathbf{a b}} \pm 0.26$ & $0.29^{\mathrm{a}} \pm 0.09$ & $0.43^{\mathrm{ab}} \pm 0.11$ & $0.43^{\mathrm{ab}} \pm 0.11$ & $0.33^{\mathrm{ab}} \pm 0.06$ & $* * *$ \\
\hline Depth (m) & $1.71^{b} \pm 0.48$ & $1.58^{\mathbf{b}} \pm 0.36$ & $1.05^{\mathrm{a}} \pm 0.24$ & $1.11^{\mathrm{a}} \pm 0.18$ & $0.94^{\mathrm{a}} \pm 0.33$ & $1.49^{b} \pm 0.37$ & $1.71^{b} \pm 0.46$ & $2.12^{\mathrm{c}} \pm 0.27$ & $* * *$ \\
\hline $\begin{array}{l}\text { Temperature } \\
\left({ }^{\circ} \mathrm{C}\right)\end{array}$ & $29.2^{\mathrm{ab}} \pm 0.9$ & $30.26^{\mathbf{b c}} \pm 0.8$ & $30.8^{c} \pm 0.8$ & $30.2^{\mathrm{bc}} \pm 1.28$ & $29.9^{\mathrm{abc}} \pm 1.2$ & $28.9^{\mathrm{ab}} \pm 1.07$ & $28.9^{\mathrm{ab}} \pm 0.95$ & $28.5^{\mathrm{a}} \pm 1.23$ & $* * *$ \\
\hline $\begin{array}{c}\text { Dissolved } \\
\text { oxygen }\left(\mathrm{mg} \cdot \mathrm{L}^{-1}\right)\end{array}$ & $2.16^{\mathrm{a}} \pm 1.09$ & $2.85^{\mathrm{a}} \pm 1.46$ & $2.76^{\mathrm{a}} \pm 1.33$ & $2.66^{\mathrm{a}} \pm 1.59$ & $2.58^{\mathrm{a}} \pm 1.38$ & $3.36^{\mathrm{a}} \pm 1.9$ & $3.47^{\mathrm{a}} \pm 1.9$ & $2.65^{\mathbf{a}} \pm 1.38$ & NS \\
\hline $\mathrm{pH}$ & $6.6^{\mathbf{a}} \pm 0.54$ & $6.5^{\mathrm{a}} \pm 0.43$ & $6.5^{\mathbf{a}} \pm 0.60$ & $6.6^{\mathbf{a}} \pm 0.49$ & $7.16^{\mathbf{b c}} \pm 0.31$ & $7.49^{\text {cd }} \pm 0.57$ & $7.80^{\mathbf{d}} \pm 0.17$ & $6.88^{\mathrm{ab}} \pm 0.28$ & * \\
\hline Salinity (\%o) & $0.01^{\mathrm{a}} \pm 0.03$ & $0.02^{\mathrm{a}} \pm 0.07$ & $0.01^{\mathrm{a}} \pm 0.03$ & $0.03^{a} \pm 0.1$ & $1.94^{\mathbf{b}} \pm 1.90$ & $1.42^{b} \pm 1.67$ & $2.03^{\mathbf{b}} \pm 2.52$ & $0^{\mathbf{a}} \pm 0$ & $* * *$ \\
\hline $\begin{array}{l}\text { Conductivity } \\
\left(\mu \mathrm{S} \cdot \mathrm{cm}^{-1}\right)\end{array}$ & $165.5^{\mathbf{a}} \pm 115.2$ & $152.92^{\mathrm{a}} \pm 30.75$ & $152.3^{a} \pm 97.7$ & $155.87^{\mathrm{a}} \pm 89.83$ & $3569^{\mathbf{b}} \pm 3317$ & $3474^{b} \pm 4686$ & $3685^{\mathbf{b}} \pm 4332$ & $87.9^{a} \pm 15.5$ & $* * *$ \\
\hline $\operatorname{TDS}\left(\mathrm{mg} \cdot \mathrm{L}^{-1}\right)$ & $165.3^{\mathrm{a}} \pm 115.1$ & $152.44^{\mathrm{a}} \pm 129.15$ & $152.9^{a} \pm 98.5$ & $156.33^{\mathrm{a}} \pm 90.27$ & $3576^{\mathbf{b}} \pm 3328$ & $3467^{b} \pm 4691$ & $3656^{\mathbf{b}} \pm 4234$ & $87.89^{a} \pm 15.46$ & $* * *$ \\
\hline $\mathrm{PO}_{4}^{3-} \quad\left(\mu \mathrm{g} \cdot \mathrm{L}^{-1}\right)$ & $172^{a} \pm 282$ & $131^{a} \pm 205$ & $112^{\mathrm{a}} \pm 164$ & $284^{a} \pm 572$ & $184^{a} \pm 330$ & $206^{a} \pm 340$ & $162^{a} \pm 236$ & $38^{\mathrm{a}} \pm 62$ & NS \\
\hline $\mathrm{NH}_{4}^{+} \quad\left(\mu \mathrm{g} \cdot \mathrm{L}^{-1}\right)$ & $337^{\mathbf{a}} \pm 133$ & $297^{a} \pm 94$ & $313^{\mathrm{a}} \pm 146$ & $420^{\mathrm{a}} \pm 245$ & $454^{\mathrm{a}} \pm 296$ & $356^{\mathbf{a}} \pm 108$ & $348^{a} \pm 106$ & $264^{\mathrm{a}} \pm 157$ & NS \\
\hline $\mathrm{NO}_{3}^{-}\left(\mu \mathrm{g} \cdot \mathrm{L}^{-1}\right)$ & $22^{a} \pm 24$ & $24^{\mathrm{a}} \pm 15$ & $68^{a} \pm 72$ & $19^{a} \pm 9$ & $77^{a}-69$ & $75^{a}-58$ & $77^{a}-85$ & $69^{a}-62$ & NS \\
\hline $\mathrm{NO}_{2}^{-}\left(\mu \mathrm{g} \cdot \mathrm{L}^{-1}\right)$ & $69^{a} \pm 125$ & $23^{a} \pm 16$ & $43^{a} \pm 66$ & $29^{a} \pm 24$ & $72^{a} \pm 112$ & $39^{a} \pm 34$ & $25^{a} \pm 13$ & $30^{a} \pm 21$ & NS \\
\hline
\end{tabular}

${ }_{\mathrm{a}, \mathrm{b}, \mathrm{c}, \mathrm{d}}$ In each line, means with the same letters as superscripts are not significantly different $(\mathrm{p}>0.05)$. NS $(\mathrm{p}>0.05){ }^{*}(\mathrm{p}<0.05)^{* *}(\mathrm{p}<0.01)^{* * *}(\mathrm{p}<0.001)$. 


\subsubsection{Temporal Patterns}

Averaged over all sites, the month of November had the lowest water depth and the highest temperature. In October the transparency was higher and the water depth and dissolved oxygen reached their maximum while the water had the lowest pH. Conductivity and TDS in November were higher than in previous months. Nitrogen compounds were generally higher in September but lower in November while orthophosphate presented an opposite trend.

\subsubsection{Spatial Patterns}

Table 4 shows that, averaged over the three months, Station 8 had the highest water depth but the lowest temperature. Transparency was the highest at Station 1, whereas Station 4 showed the lowest value. The Stations 1 , 2, 3, 4 and 8 have analogous low $\mathrm{pH}$ value while Station 7 (close to the ocean) has the highest $\mathrm{pH}$.

The table of correlations (Table 5) shows that the total nitrogen is positively correlated to total phosphorus $(\mathrm{r}=$ 0.99; $\mathrm{p}<0.01)$ and weakly positively correlated with orthophosphate $(\mathrm{r}=0.50 ; \mathrm{p}<0.05)$ and ammonium $(\mathrm{r}=$ $0.51 ; \mathrm{p}<0.05)$ which maintain between them a positive correlation $(\mathrm{r}=0.9 ; \mathrm{p}<0.01)$. Temperature has a strong negative correlation with nitrite $(r=0.7 ; p<0.01)$.

\subsection{Characterization of the Lake Using Macroinvertebrates}

A total of 66 taxa including Arthropoda, Mollusca and Annelida were obtained during the survey [41]. Figure 3

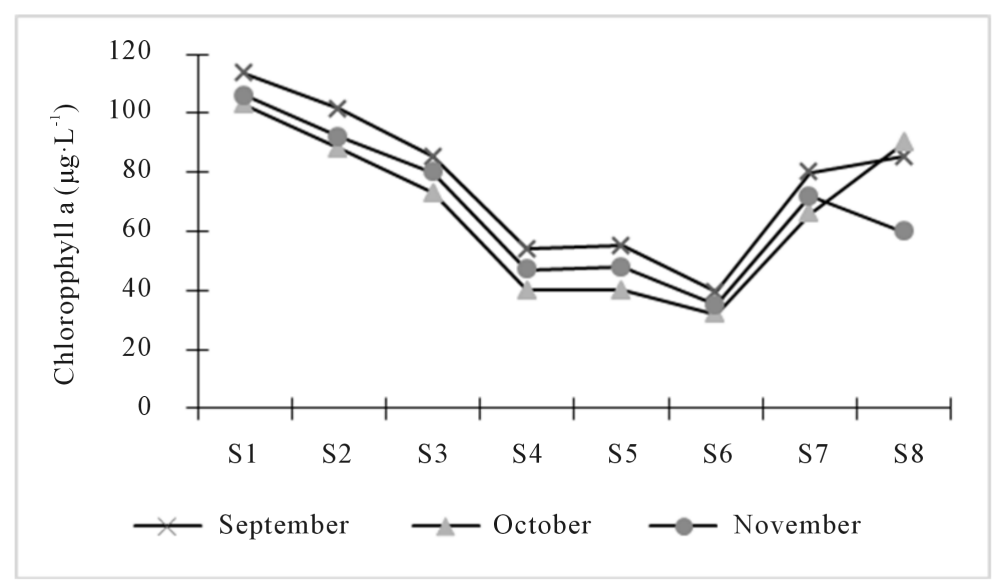

Figure 2. Spatial and temporal variation of chlorophyll a concentration of Lake Nokoue during survey.

Table 5. Spearman's rank correlation between the main nutrients, Chl_a and some physicochemical parameters.

\begin{tabular}{|c|c|c|c|c|c|c|c|c|c|}
\hline Variable & $\mathrm{PT}$ & NT & Chl_a & $\mathrm{T}$ & Oxy & Tran & $\mathrm{PO}_{4}^{3--}$ & $\mathrm{NH}_{4}^{+}$ & $\mathrm{NO}_{3}^{-}$ \\
\hline PT & --- & & & & & & & & \\
\hline NT & $0.99^{* *}$ & --- & & & & & & & \\
\hline Chl_a & -0.24 & -0.25 & --- & & & & & & \\
\hline $\mathrm{T}$ & 0.30 & 0.30 & 0.33 & --- & & & & & \\
\hline Oxy & 0.22 & -0.24 & -0.38 & -0.52 & --- & & & & \\
\hline Tran & 0.20 & 0.20 & -0.07 & 0.39 & 0.09 & --- & & & \\
\hline $\mathrm{PO}_{4}^{3-}$ & 0.47 & $0.50^{*}$ & 0.49 & -0.20 & $-0.59^{*}$ & 0.19 & --- & & \\
\hline $\mathrm{NH}_{4}^{+}$ & 0.47 & $0.51^{*}$ & -0.47 & 0.08 & 0.41 & 0.09 & $0.90^{* *}$ & --- & \\
\hline $\mathrm{NO}_{3}^{-}$ & -0.26 & -0.26 & $0.50 *$ & -0.16 & -0.03 & -0.03 & -0.24 & -0.20 & \\
\hline $\mathrm{NO}_{2}^{-}$ & 0.22 & 0.23 & -0.28 & $-0.7^{* *}$ & -0.01 & -0.34 & 0.15 & 0.26 & 0.06 \\
\hline
\end{tabular}

${ }^{* *}$ Correlation is significant at $0.01 ;{ }^{*}$ Correlation is significant at 0.05 . 
shows spatial and temporal variation of the Nokoue Lake Hilsenhoff's Index during the study. The water quality is changing both spatially and temporally. Indeed, Stations 1 and 2 show little temporal variation of the macroinvertebrate assemblages. The other stations exhibit a higher FBI in September and October (6, 7 and 8) or only in October (3, 4 and 5). In November, FBI values was lower at Stations 6, 7 and 8 (medium quality) whereas Stations 1 and 4 had higher values (very bad quality). Generally we obtain lower FBI values at Stations 5 and 8.

Pairwise Spearman's rank correlations between this index and the concentration of chlorophyll a is 0.784 ( $\mathrm{p}=$ 0.035). So when algal biomass increases, the value of the index also increases and reflects a deterioration of the water quality.

The monthly taxonomic distribution of macroinvertebrates based on the Factorial Correspondence Analysis (FCA) is presented in Figures 4-6. The FCA made on the abundance of macroinvertebrates collected relates the community structure at different stations.

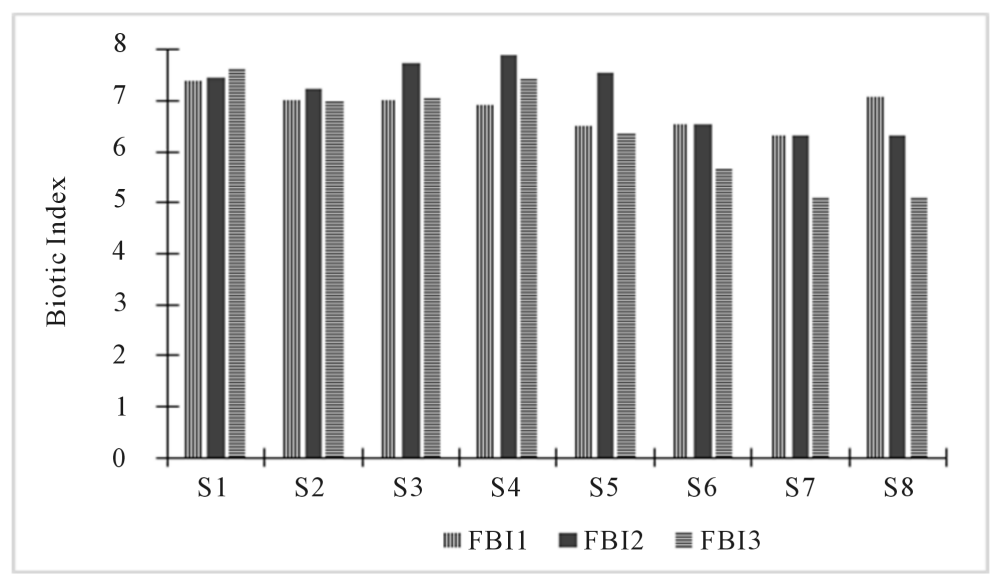

Figure 3. Variation of Hilsenhoff's Family Biotic Index of Nokoue Lake study stations during September (FBI 1), October (FBI 2) and November (FBI 3).

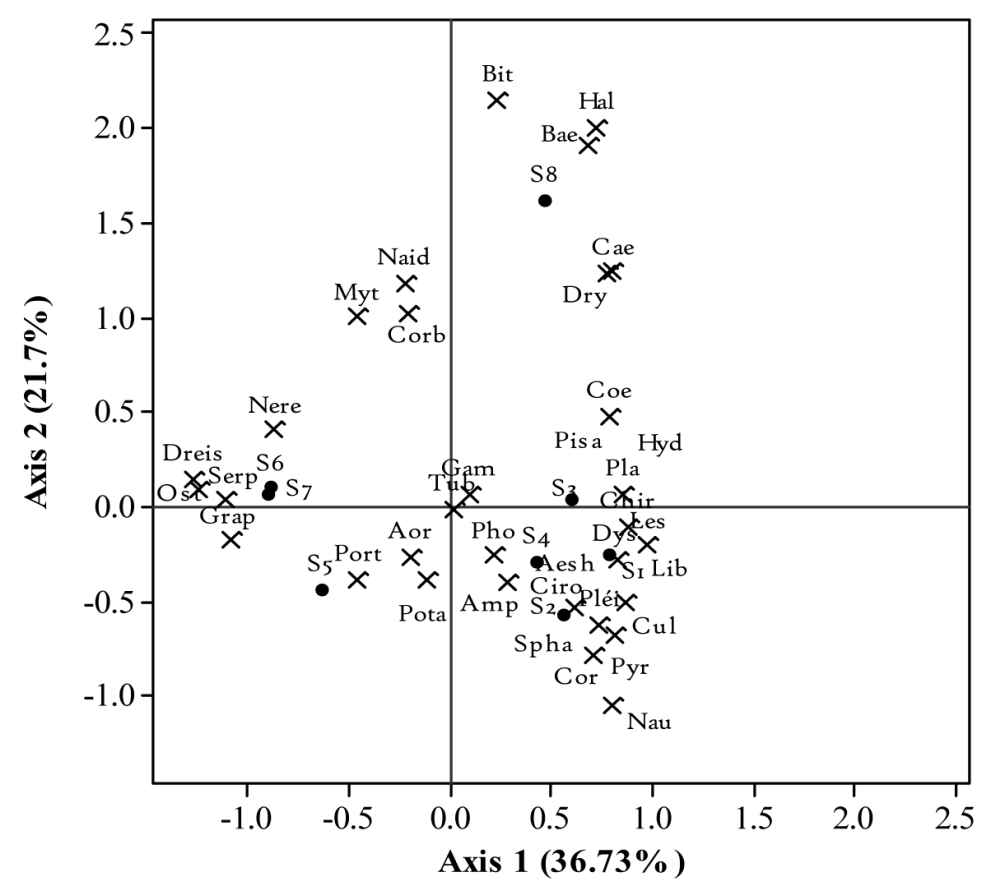

Figure 4. Biplot of Factorial Correspondence Analysis (FCA) showing distribution of different macroinvertebrate families in relation to sampling stations of Nokoue Lake in September 2014. Abbreviation is described in Table 2. 


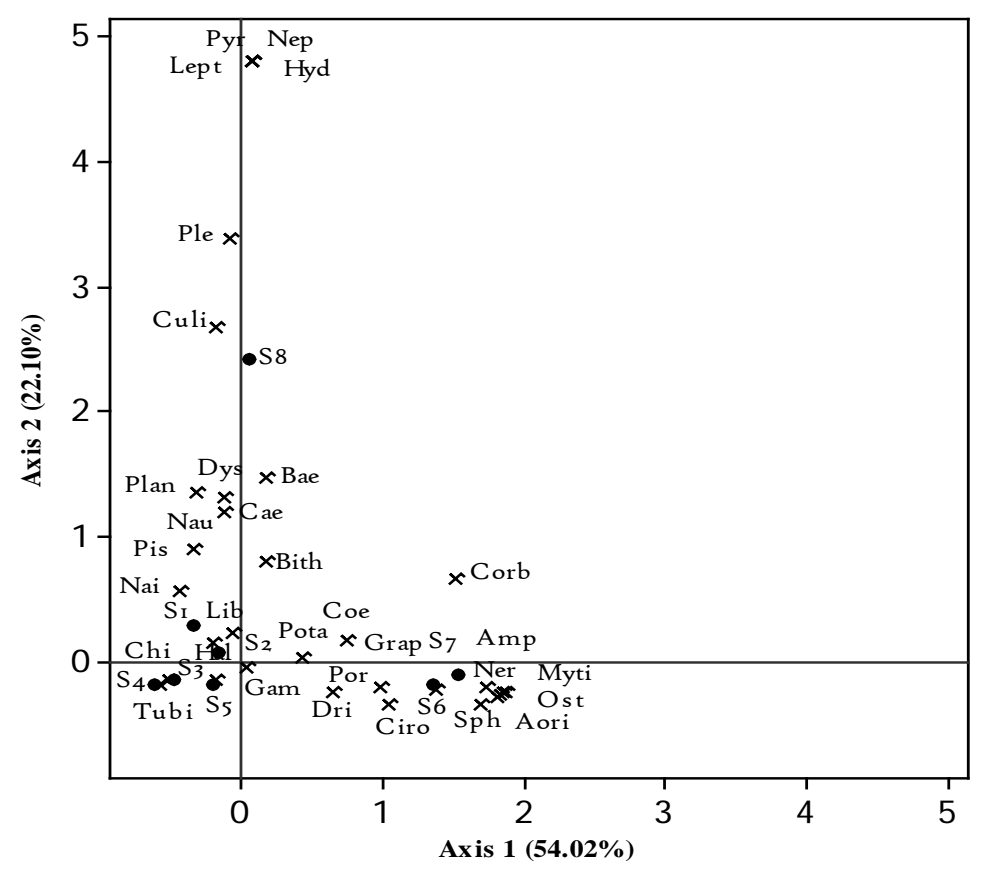

Figure 5. Biplot of Factorial Correspondence Analysis (FCA) showing distribution of different macroinvertebrate families in relation to sampling stations of Nokoue Lake in October 2014. Abbreviation is described in Table 2.

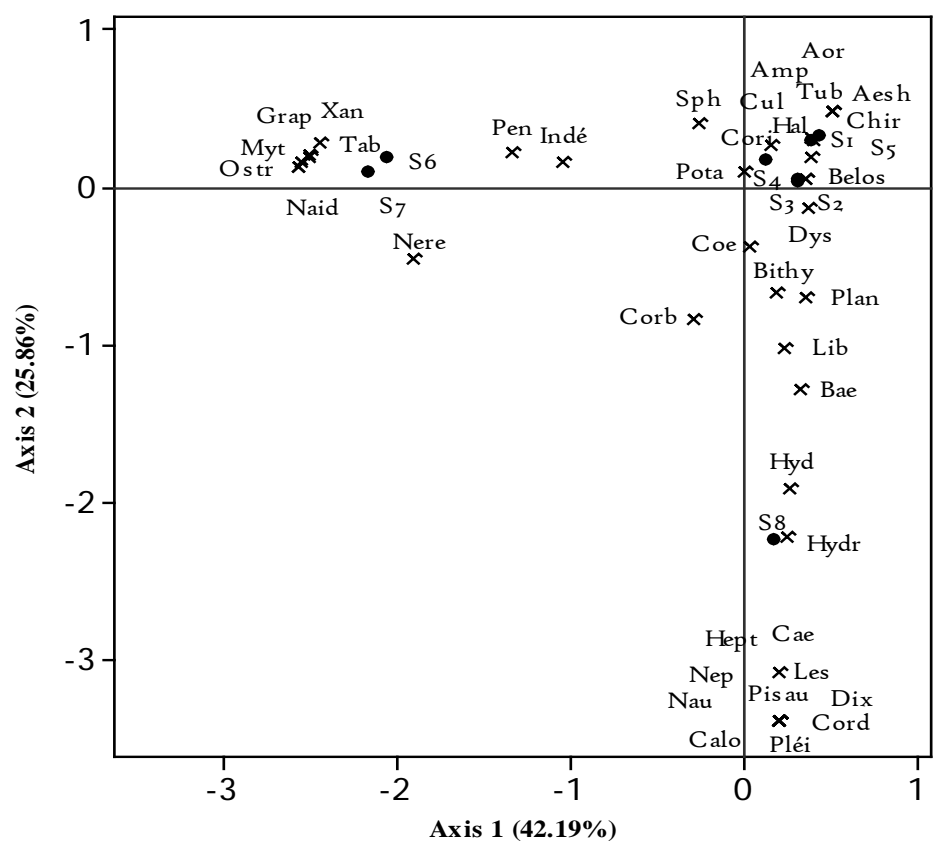

Figure 6. Biplot of Factorial Correspondence Analysis (FCA) showing distribution of different macroinvertebrate families in relation to sampling stations of Nokoue Lake in November 2014. Abbreviation is described in Table 2.

\subsubsection{Macroinvertebrates in September}

In September, the first FCA axis explained $36.73 \%$ of the observed variability in species abundance whereas the second axis captured about $21.7 \%$ of the variance for a total of $58.3 \%$. Station 8 , communicating with the Oueme river and Porto-Novo lagoon, is characterized by a group of essential polluo-resistant taxa comprising 
Bithynidae, Baetidae, Haliplidae, Caenidae and to a lesser extent Naididae. In the South, there are two clusters of sites, Stations 5, 6 and 7 (left) and Stations 1, 2, 3 and 4 (right). In the first group where the salinity is often high, Dreissenidae, Ostreidae, Grapsidae, Serpulidae, Nereidae, Portunidae, Mytilidae, Aoridae and to a lesser extent Naididae are well represented. The Stations of the second group are generally preferred environments for insects and Oligochaeta and specifically for highly polluo-resistant such as Libellulidae, Lestidae, Coenagrionidae, Culicidae, Dystiscidae and Chironomidae.

\subsubsection{Macroinvertebrates in October}

In October, overall $77.02 \%$ of variation in species abundance was accounted by the FCA with $54.92 \%$ for axis 1 and $22.10 \%$ for axis 2 . The structure is not the same as previous month, though it is not too far away either. Indeed, the distribution of families was done primarily along both axes. Station 5 forms with Stations 1, 2, 3 and 4 a group which is a preferred habitat for many low-polluo sensitive taxa: Potamididae, Dystiscidae, Naididae, Culicidae, Gammaridae, Haliplidae, Tubificidae, together with some Baetidae, Caenidae Coenagrionidae and Libellulidae on some stations. Stations 7 and 8 (78.9\% similarity) are strongly correlated with axis 1 and include Mytilidae, Amphilochidae, Ostreidae, and Aoridae, Nereidae, Grapsidae Cirolanidae and Portunidae. Station 8 as in September is on the far North. It is very well represented by axis 2 and is an preferred by Leptophlebiidae, Nepidae, Corbulidae, Pyralidae, Culicidae, Hydrophilidae, Pleidae, and to a lesser extent by Baetidae, Caenidae, Planorbidae and Dystiscidae representing medium tolerance taxa with the exception of a few.

\subsubsection{Macroinvertebrates in November}

Analysis of Figure 6 resulting from the FCA based on species abundance of November explained $68.05 \%$ of the observed variability of structure which $42.19 \%$ for axis 1 and $25.86 \%$ for axis 2 . The structure is less strict except for Station 8. It is well represented by the axis 2 and always contained much more exclusive taxa such as Lestidae, Calopterygidae, Corduliidae, Heptagenidae, Dixidae, Pleidae, Nepidae, Naucoridae, Pisauridae and in high proportion Caenidae, Baetidae and many others which are both polluo-sensitive and polluo-resistant. Up in the left corner, the nearest stations of the ocean were preferred by Grapsidae, Mytilidae, Tabanidae, Nereidae, and other taxa such as Peneaeidae shared with stations of the group on the right. These are Stations 1, 2, 3, 4 and 5 consists of medium tolerance taxa to pollution and polluo-resistant taxa like the Chironomidae and Coenagrionidae. The composition of that stations group is not completely homogeneous, despite having enough common families with the previous two groups.

A correlation between biological and physicochemical variables that can inform on the state of pollution is shown in Table 6 and Table 7. Analysis of Table 6 showed that the three diversity indices are highly correlated but weakly with the taxon number of which they depend. Oligochaeta percentage shows no significant correlation with other variables like the taxa number of EPT (N_EPT) and the EPT\% but which have a very strong positive correlation between them. Percentage of insects are negatively correlated to diversities indices $\mathrm{H}$ and $\mathrm{E}$ but positively to Simpson's index (Ds). These correlations are strong with Chironomidae percentage. Biotic Index is more strongly correlated to the percentage of Chironomidae than the percentage of insects, the diversities indices (Ds, H' and E).

Table 6. Spearman's rank correlation between biological indices of pollution.

\begin{tabular}{|c|c|c|c|c|c|c|c|c|c|}
\hline Variable & $\mathrm{H}^{\prime}$ & E & S & Ds & N_EPT & EPT & $\%$ Ins & $\%$ Oli & \%Chir \\
\hline E & $0.92^{* *}$ & --- & & & & & & & \\
\hline S & $0.73^{* *}$ & $0.42^{*}$ & -- & & & & & & \\
\hline Ds & $-0.96^{* *}$ & $-0.98^{* *}$ & $-0.55^{* *}$ & --- & & & & & \\
\hline N_EPT & 0.36 & 0.25 & 0.39 & -0.28 & --- & & & & \\
\hline EPT & $0.42^{*}$ & 0.34 & 0.38 & -0.33 & $0.93^{* *}$ & --- & & & \\
\hline$\%$ Ins & $-0.55^{* *}$ & $-0.66^{* *}$ & -0.17 & $0.66^{* *}$ & 0.28 & 0.31 & --- & & \\
\hline$\%$ Oli & 0.14 & 0.12 & 0.13 & -0.16 & 0.02 & -0.03 & -0.06 & --- & \\
\hline \%Chir & $-0.78^{* *}$ & $-0.85^{* *}$ & -0.36 & $0.85^{* *}$ & 0.01 & -0.02 & $0.91^{* *}$ & -0.05 & --- \\
\hline FBI & $-0.64^{* *}$ & $-0.68^{* *}$ & -0.33 & $0.68^{* *}$ & -0.08 & -0.11 & $0.68^{* *}$ & 0.08 & $0.81^{* *}$ \\
\hline
\end{tabular}

${ }^{* *}$ Correlation is significant at 0.01 . ${ }^{*}$ Correlation is significant at 0.05 . 
Table 7. Spearman's rank correlation of Axis 1 of the FCA with some structure and physicochemical variables during the three months. $\mathrm{S}=$ September. $\mathrm{O}=$ October. $\mathrm{N}=$ November.

\begin{tabular}{cccccccccccccc}
\hline Axis 1 & H' & \%Chir & FBI & Cond & Sal & Temp & Pf & Trans & pH & Chl_a & NT & PT & Oxy \\
\hline S & 0.34 & $0.91^{* *}$ & $0.95^{* *}$ & $-0.86^{* *}$ & -0.39 & 0.54 & 0.47 & 0.53 & $-0.88^{* *}$ & $0.67^{*}$ & $0.72^{*}$ & $0.62^{*}$ & -0.35 \\
O & 0.63 & $-0.90^{* *}$ & $-0.82^{*}$ & $0.74^{*}$ & 0.63 & -0.52 & 0.56 & -0.36 & $0.88^{* *}$ & $-0.57^{*}$ & $-0.53^{*}$ & $-0.84^{* *}$ & 0.34 \\
N & -0.48 & $0.72^{*}$ & $0.69^{*}$ & $-0.82^{*}$ & $-0.83^{*}$ & 0.45 & -0.19 & $-0.76^{*}$ & $-0.80^{*}$ & $0.47^{*}$ & $0.41^{*}$ & $0.67^{*}$ & $-0.84^{* *}$ \\
\hline
\end{tabular}

${ }^{* *}$ Correlation is significant at $0.01 .{ }^{*}$ Correlation is significant at 0.05 .

The correlation analysis of Axis 1 of the FCA with different variables showed that the distribution of taxa is correlated with an ecological gradient and it has affinities with structural statistical variables. Environmental variables that influence the distribution of organisms are conductivity and $\mathrm{pH}$ during all months and only in November for transparency, salinity and dissolved oxygen. Axis 1 of the FCA is also correlated with chlorophyll a values, nitrogenous and phosphorous matter. Better, the percentage of Chironomidae and Biotic Index synthesis variables are very well correlated to axis 1 which reflects a taxonomic distribution for all months.

\section{Discussion}

\subsection{Water Quality Status of Nokoue Lake}

The physicochemical variables allow to access ecosystem water quality variation from upstream to downstream [42] [43] for a good management. The depth is higher in October and deviates from the average value of $1.5 \mathrm{~m}$ reported by [5] due to direct precipitation and water intake of the Sô River and Oueme River which also increases transparency. Temperature is high and characterize a poor water quality [44] and is likely to influence many metabolic reactions and biological processes such as photosynthesis and the solubility of salts and gases required for the balance of the aquatic ecosystem. This situation partly explains the dissolved oxygen values $<5$ $\mathrm{mg} \cdot \mathrm{L}^{-1}$ measured on most stations, content required for good quality habitats favorable for survival of aquatic organisms [45]-[47]. $\mathrm{pH}$ values reveal that apart from stations close to the ocean that are alkaline, other stations are acidic and the lowest $\mathrm{pH}$ were obtained in October (high water). The acidity of the lake in October would be linked to the nature of the water it receives from these tributaries. Indeed, the water from the Oueme River and the Sô river crossed land and agricultural land and received effluent that enriched them in different minerals and materials whose decomposition has increased the activity of bacteria and acidify the water [7] [26] [40] [48] [49]. Basic $\mathrm{pH}$ obtained at the Stations 5, 6 and 7 would be due to salinity in these stations because salt water usually have a higher $\mathrm{pH}$ [50]. Acidic $\mathrm{pH}$ increases the risk of presence of metals and gas in a more toxic form. The salinity of the Nokoue Lake varies from one month to another. It is higher in November without exceeding the limits of brackish water, similar to [5] [7] [10] [51] conclusions. The difference between stations can be explained by several factors like dilution and tides as related by [51]-[53]. Generally, the nitrogenous materials (ammonium, nitrite, nitrate and total nitrogen) and phosphorus (orthophosphate and total phosphorus) are higher in the resorts of Stations 1 and 5 but lower at Station 8. This seems to highlight the impact of urban discharges, agricultural and domestic. Nitrite concentrations $\left(<0.02 \mathrm{mg} \cdot \mathrm{L}^{-1}\right)$ and nitrate $\left(<0.5 \mathrm{mg} \cdot \mathrm{L}^{-1}\right)$ obtained are lower than the levels (nitrites $<0.7 \mathrm{mg} \cdot \mathrm{L}^{-1}$ and nitrates $<16 \mathrm{mg} \cdot \mathrm{L}^{-1}$ ) obtained previously by [51] in the same period. The difference can be explained by the lack of similarity between the stations sampled, currently available organic load in the lake, climate variability and temperature. Indeed, the amount of nutrients varies in space (from upstream to downstream and depends on human activities), and is dependent on the rate of decomposition of branches used for building acadjas [20] [26]. $\mathrm{NH}_{4}^{+}$concentrations of Nokoue Lake are significantly $(\mathrm{P}<0.05)$ higher than those of nitrites and nitrates. This observation can be explained by organic matter intake supports the ammonification process at the expense of nitrification, done by reducing bacteria (Nitrosomonas sp. and Nitrobacter sp.) and this in the presence of probable quantities of toxic materials [26] [50] [54]. Larger nitrate levels than those of nitrite were also observed at Stations 5, 6, 7, and 8. Specific above findings are related to intake of pesticides (Oueme) and spill oil products (Station 8), metals and domestic toxic waste dumps of Dantokpa Market (Stations 6 and 7) and intake of toxic urban effluent (Station 5). The levels of phosphates obtained were above the admissible limit of $0.5 \mathrm{mg} \cdot \mathrm{L}^{-1}$ [29], and raise problems of eutrophication on the lake (proliferation of water hyacinths) because of their essential role in the rigidity stems, root development and smooth running of plant reproduction. The positive correlations between the reported amounts of Total Nitrogen and Total Phos- 
phorus confirm the problem of environmental enrichment and its degradation. The nitrogen and phosphorus compounds are used to properly assess the water quality [13] [55]. Chlorophyll a concentrations are determined by nitrogen compounds and remain above the limit of $40 \mu \mathrm{g} \cdot \mathrm{L}^{-1}$ characterizes eutrophic environments. Based on the principle of minimum law, the limiting factor that determines algal biomass is nitrogen, as the N/P ratio is less than 2.5 at all stations (normal equilibrium ratio: $\mathrm{N} / \mathrm{P}=16$ ). The trend is confirmed by the correlation obtained between chlorophyll a and nitrate.

\subsection{Macroinvertebrates as Biological Indicators of Pollution}

Despite the differences in precision with other indices, the Family Biotic Index (FBI) is a very good biological indicator of water quality [13] [56]. As shown in the results, concentration of chlorophyll a and diversity indices did not show significant differences while FBI shows organic pollution but to different degrees. According to [13] [57], many taxa do not react the same way to different degrees of pollution. Organism tolerances must be used because they also better reveal the extent of pollution compared to the structure of statistical variables. Moderately polluo-resistant taxa were harvested in September while brackish families with medium tolerance to pollution were obtained in October. Thus, in two different habitats where there are differences of depth, current velocity and substrate, diversity indices cannot inform effectively on pollution if it is extreme (good or bad) due to the difference in organisms already imposed by environmental characteristics. Nevertheless, despite their inertia, diversity indices can be useful if they are designed with structural statistical variables [36]. This is supported by the correlation results maintained between biological indices. Indeed, Chironomidae multiply in environmental conditions difficult to bear for other taxa (Shannon diversity and equitability low but high indices Simpson) and reflect an environment polluted with high FBI. This biological capacity of organic pollution by Chironomidae larvae was proven by [29] and confirmed by [58] respectively in the Niger River and the Ethiopian rivers. There was also a positive correlation between diversity and the percentage of insects. The latter is less related to the FBI as insects not only abound Chironomidae but both polluo-sensitive taxa. Aquatic insects are good indicators of pollution [59]. The percentage of Ephemeroptera, Plecoptera and Trichoptera (EPT), and that of Oligochaeta have not yielded significant results because of their low presence in high salinity stations. In these stations include other polluo-resistant organisms such as Polychaeta groups and Potamididae. The strong correlations between diversity indices are due to the high dependence in the calculation of these statistical variables.

Stations have neither the same structure nor the same composition during the study, i.e. in time and in space. Despite these variations, Chironomidae percentage and FBI remain efficient and flexible in their ability to characterize the environmental pollution. If organic methods are able to detect pollution, environmental variables allow to know the causes. Both methods are therefore complementary [12]. A similar observation is made in this study. In the present investigation total nitrogen, total phosphorus, Chlorophyll a concentration and Chironomidae percentage maintain together a positive correlation but negative correlation with dissolved oxygen. The environmental variables that influence the structure of macroinvertebrates are mainly the $\mathrm{pH}$, conductivity, Chlorophyll a, nitrogen and phosphorus compounds. Sometimes, salinity and dissolved oxygen also act as ecological gradients. In low water especially in the stations close to the sea, there is a saline intrusion and a water pollution control that promote better aeration of the lake and consequently influences the distribution of organisms [7]. Some of the environmental characteristics like dissolved oxygen, Chlorophyll a, total nitrogen and total phosphorus are contributing to eutrophication process in Nokoue Lake and probably have had effects on macroin-vertebrate community. Biological variables most important are Chironomidae percentage and FBI.

\section{Conclusions}

Environment characteristics changing of Nokoue Lake are due to his role as ultimate natural receptor of the Oueme River, saline intrusion, local climate and human activities. The latter is the leading cause of environment pollution confirmed by chlorophyll a, total nitrogen and total phosphorus concentration.

The structure of macroinvertebrates varies month by month and is mainly a reflection of the evolution of mineralization variables, oxygen, salinity and nutrients (nitrogen and phosphorus). The percentage of Chironomidae was very effective in characterizing the structure. Macroinvertebrates can be used as bio-indicators through the calculation of the Family Biotic Index (FBI) of these macroinvertebrates. This index also includes the trophic state of the environment and is a powerful tool for characterizing organic pollution. It is more effec- 
tive than the other diversity indices. Regular monitoring and preventive measures are required for Nokoue Lake.

Despite the promising results on the biological capacity (organic pollution) of macroinvertebrates, they remain preliminary view of season study, collection tools, the small number of sampling stations, frequencies and limited sampling time. Further investigation should be made by combining other lakes for best results that could provide easy and inexpensive monitoring of the water quality of Nokoue Lake.

\section{Acknowledgements}

Internship travel grant for taxonomy capacity building provided by Belgian National Focal Point to the Global Taxonomy Initiative to Hamed Odountan is greatly appreciated. The authors are grateful to Dr Luc Janssens de Bisthoven (Royal Belgian Institute for Natural Sciences, CEBioS programme), who accepts spontaneously to help, for his valuable comments, suggestion and for correcting the English that improved the paper.

\section{References}

[1] Masese, F.O., Raburu, P.O. and Muchiri, M. (2009) A Preliminary Benthic Macroinvertebrate Index of Biotic Integrity (B-IBI) for Monitoring the Moiben River, Lake Victoria Basin, Kenya. African Journal of Aquatic Science, 34, 1-14. http://dx.doi.org/10.2989/AJAS.2009.34.1.1.726

[2] Trolle, D., Halmiton, D.P., Pilditch, C.A., Duggan, I.C. and Jeppesen, E. (2010) Predicting the Effects of Climate Change on Trophic Status of three Morphologically Varing Lakes: Implications for Lake Restoration and Management. Environmental Modelling and Software, 26, 354-370. http://dx.doi.org/10.1016/j.envsoft.2010.08.009

[3] Jackson, R.B., Carpenter, S.R., Dahm, C.N., Mcknight, D.M., Naiman, R.J., Postal, S.L. and Running, S.W. (2001) Water in a Changing World. Ecological Applications, 11, 1027-1045. http://dx.doi.org/10.1890/1051-0761(2001)011[1027:WIACW]2.0.CO;2

[4] Ogutu-Ohwayo, R., Hecky, R.E., Cohen, S.A. and Kauf, L. (1997) Human Impacts on the African Great Lakes. Environmental Biology of Fishes, 50, 117-137. http://dx.doi.org/10.1023/A:1007320932349

[5] Mama, D. (2010) Methodology and Results of the Diagnostics Eutrophication of Nokoue Lake (Benin). PhD Thesis, University of Limoges, Limoges, 157 p.

[6] Zohary, T., Pais-Madeira, A.M., Robarts, R. and Hambright, K.D. (1996) Interannual Phytoplankton Dynamics of a Hypertrophic African Lake. Archives of Hydrobiologya, 136, 105-126.

[7] Gnohossou, P. (2006) The Benthic Fauna of a West African Lagoon (Nokoue Lake in Benin), Diversity, Abundance Temporal and Spatial Variations, Place in the Food Chain. PhD Thesis, Ecole Nationale Supérieure Agronomique de Toulouse (ENSAT), Auzeville-Tolosane.

[8] Lalèyê, P. (1995) Compared Ecology of Two Species of Chrisichthys, Catfish Fish (Claroteidae) of Lagoon Complex Nokoue Lake-Porto-Novo Lagoon in Benin. PhD Thesis in Sciences, University of Liege, Liège.

[9] Aglinglo, A.C. (1998) Fish Production in Acadjas System of Nokoue Lake and Porto-Novo lagoon in Benin: Current Situation and Prospects for Rational Management. MSc Thesis in Earth and Life Sciences, University of Liege, Liège.

[10] Goussanou, A. (2012) Diversity of Phytoplankton of Nokoue Lake. MSc Thesis, University of Abomey-Calavi, Cotonou.

[11] Karr, J.R., Fausch, K.D., Angermeier, P.L., Yant, P.R. and Schlosser, I.J. (1986) Assessing Biological Integrity in Running Waters: A Method Its Rationale. Special Publication 5, Illinois Natural History Survey, Champaign.

[12] Rioux, S. and Gagnon, F. (2001) Development of a Biotic Index to Evaluate the Health of Small Streams of Agricultural Environment in the Lower St.-Laurent Management Branch of the Fauna of the Region of the Lower St. Laurent. Bape Bio Document.

[13] Xu, M., Wang, Z., Duan, X. and Pan, B. (2014) Effects of Pollution on Macroinvertebrates and Water Quality BioAssessment. Hydrobiologia, 729, 247-259. http://dx.doi.org/10.1007/s10750-013-1504-y

[14] Hart, B.T., Maher, B. and Lawrence, I. (1999) New Generation Water Quality Guidelines for Ecosystem Protection. Freshwater Biology, 41, 347-359. http://dx.doi.org/10.1046/j.1365-2427.1999.00435.x

[15] Touzin, D. (2008) Use of Benthic Macroinvertebrates to Assess the Deteriorating Quality of Rivers Water in Quebec. Agricultural Engineering Thesis, University of Laval, Québec City.

[16] Clarke, K.R. and Warwick, R.M. (2001) Changes in Marine Communities: An Approach to Statistical Analysis and Interpretation. 2nd Edition, PRIMER-E: Plymouth Marine Laboratory, Plymouth.

[17] Gnohossou, P. (2002) Influence of Organic Pollution on Nokoue Lake Invertebrates. Thorough Agronomy Thesis, National School of Agronomy of Toulouse, Toulouse. 
[18] Adandedjan, D., Lalèyè, P. and Gourene, G. (2012) Macroinvertebrates Communities of a Coastal Lagoon in Southern Benin. International Journal of Biological and Chemical Science, 6, 1233-125. http://dx.doi.org/10.4314/ijbcs.v6i3.27

[19] Adandedjan, D., Montcho, A.S., Chikou, A., Lalèyè, P. and Gourene, G. (2013) Caractérisation des peuplements de macroinvertébrés benthiques à l'aide de la Carte Auto-organisatrice (SOM). Comptes Rendus Biologies, 336, $244-248$. http://dx.doi.org/10.1016/j.crvi.2013.04.009

[20] Mama, D., Deluchat, V., Bowen, J., Chouti, W., Yao, B., Gnon, B. and Baudu, M. (2011) Characterization of a Lagunaire System in Tropical area: Case of Nokoue Lake (Benin). European Journal of Scientific Research, 56, 516-528.

[21] Lalèyè, P., Niyonkuru, C., Moreau, J. and Teugels, G.G. (2003) Spatial and Seasonal Distribution of the Ichthyofauna of Lake Nokoué, Benin, West Africa. African Journal of Aquatic Sciences, 2, 151-161. http://dx.doi.org/10.2989/16085910309503779

[22] Olopade, O.A., Taiwo, O.I., Ajibade, D. and Aluko, F.A. (2008) Community Based Fishery Management: A Case Study of Acadjas Method of Fishing on the Badagry Creek, Ogun State, Nigeria. Journal of Agriculture and Social Research, 8, 28-33. http://dx.doi.org/10.4314/jasr.v8i1.2882

[23] Cuffney, T.F., Gurtz, M.E. and Meador, M.R. (1993) Methods for Collecting Benthic Invertebrate Samples as Part of the National Water-Quality Assessment Program. USGS Open-File Report 93-406.

[24] Goaziou, Y. (2004) Methods of Biotic Integrity Assessment of Aquatic Environment Based on Benthic Macroinvertebrates: Training Report. Direction of Environment State Monitoring, Quebec.

[25] Moisan, J. and Pelletier, L. (2011) Sampling Protocol of Benthic Macroinvertebrate of Quebec Freshwater-Shallow Rivers with Soft Substrate. Direction of Environment State Monitoring, Ministry of Sustainable Development, Environment and Parks, Quebec.

[26] Rodier, J., Legube, B., Merlet, N., Brunet, R., Mialocq, J.-C., Leroy, P., Houssin, M., Lavison, G., Bechemin, C., Vincent, M., Rebouillon, P., Moulin, L., Chomodé, P., Dujardin, P., Gosselin, S., Seux, R. and Al Mardin, F. (2009) L'analyse de l'eau. 9è/Ed, Dunod, Paris.

[27] Lorenzen, C.J. (1967) Determination of Chlorophyll and Pheopigments: Spectrophotometric Equations. Limnology and Oceanography, 12, 343-346. http://dx.doi.org/10.4319/lo.1967.12.2.0343

[28] Viljoen, A., Cyrus, D.P. and Wepener, V. (2001) Comparison of the Density and Species Composition of Aquatic Invertebrates Found between the Roots of Eichhornia crassipes Plants from Two Coastal Lakes in Northern KwaZulu-Natal. African Journal of Aquatic Sciences, 26, 57-65. http://dx.doi.org/10.2989/16085910109503725

[29] Alhou, B. (2007) Impact of Discharges of Niamey (Niger) on the Water Quality of the River Niger. PhD Thesis, University of Namur, Belgium.

[30] Nickles, M. (1950) Shellfish Marine Molluscs of the Western Coast of Africa. West Africans Manuals, II/Ed., Paris.

[31] Villiers, A. (1952) Hemiptera (Bugs and Cicadas) of Black Africa. Initiations Africaines IX, French Institute of Black Africa, Dakar.

[32] Hayward, P. (1980) Seaside Guide: North Sea, Channel, Atlantic, and Mediterranean. Delachaux Niestlé var.pag.

[33] Durand, J.R. and Leveque, C. (1981) Aquatic Flora and Fauna of Sudanese and Sahelian Africa. ORSTOM, Paris.

[34] McCafferty, P. (1981) Aquatic Entomology. The Fisherman's and Ecologists' Illustrated Guide to Insects and Their Relatives. Jones and Bartlett Publishers, Boston and London.

[35] FAO (1992) Field Guide of Commercial Marine Resources of the Gulf of Guinea. Rome.

[36] Moisan, J. (2010) Identification Guide to Key Freshwater Benthic Macroinvertebrates Quebec_-Monitoring Voluntary Courses Shallow Water. Direction of Environment State Monitoring, Ministry of Sustainable Development, Environment and Parks, Quebec.

[37] Tachet, H., Richoux, P., Bourneau, M. and Usseglio-Polatera, P. (2010) Freshwater Invertebrates, Systematics, Biology, Ecology. CNRS Editions, Paris.

[38] Hilsenhoff, W.L. (1988) Rapid Field Assessment of Organic Pollution with a Family-Level Biotic Index. Journal of the North American Bentholoical Society, 7, 65-68. http://dx.doi.org/10.2307/1467832

[39] Glèlè Kakai, R. and Kokode, G.G. (2004) Univariate and Multivariate Techniques Statistics: Computer Applications. Technical Note Biometrics, Benin.

[40] Amri, N., Jamili, S. and Shahidian, M. (2014) A Study on the Primary Production of the Périphyton Epilithics and Biomass Macrobenthos in Kordian River (North West of Iran). International Journal of Ecosystem, 4, 75-82. http://dx.doi.org/10.5923/j.ije.20140402.05

[41] Odountan, O.H. (2015) Spatial Distribution and Structure of Benthic Macroinvertebrates of Nokoue Lake. Master’s Thesis, University of Abomey-Calavi, Benin. 
[42] Fishar, M.R., Thorne, R. and Williams, W.P. (2006) Physical-Chemical Conditions and Macroinvertebrate Fauna in the River Nile from Aswan to Cairo. African Journal of Aquatic Science, 31, 247-259. http://dx.doi.org/10.2989/16085910609503894

[43] Abdel-Hamid, M.I., Abdel-Aal, E.I. and Azzab, Y.A. (2014) Spatial Quality Improvement of a Toxic Industrial Effluent, Based on Physico-Chemistry, Algal Community Changes and Algal Bioassay. African Journal of Aquatic Science, 39, 1-16. http://dx.doi.org/10.2989/16085914.2013.870524

[44] Beaux, J.F. (1998) L’Environnement-Repères. Pratiques, Nathan, 64-71.

[45] Hodges, L. (1973) Environmental Pollution. A Survey of Emphasising Physical and Chemical Principle. Holt, Rhinehart and Winston, Inc, New York.

[46] Odokuma, L.O. and Okpokwasili, G.C. (1993) Seasonal Ecology of Hydrocarbon-Utilizing Microbes in the Surface Waters of a River. Environmental Monitoring and Assessment, 27, 175-191. http://dx.doi.org/10.1007/BF00548364

[47] Izonfuo, L.W.A. and Bariweni, A.P.T. (2001) The Effect of Urban Runoff Water and Human Activities on Some Physico-Chemical Parameters of the Epie Creek in the Niger Delta. Journal of Applied Sciences and Environmental Management, 5, 47-55. http://dx.doi.org/10.4314/jasem.v5i1.54941

[48] Sane, S. (2006) Control of Primary Production of Lake Guiers in Northern Senegal. PhD Thesis, University Cheikh Anta Diop, Dakar.

[49] Ngupula, G.W. and Kayanda, R. (2010) Benthic Macrofauna Community Composition, Abundance and Distribution in the Tanzanian and Ugandan Inshore and Offshore Waters of Lake Victoria. African Journal of Aquatic Science, 35, 185-192. http://dx.doi.org/10.2989/16085914.2010.490978

[50] Gaujous, D. (1995) Pollution of Aquatic Environments: Reminder. Tec \& Doc Lavoisier, Paris.

[51] Dovonou, F., Aina, M., Boukari, M. and Alassane, A. (2011) Physical Chemical and Bacteriological Pollution of an Aquatic Ecosystem and Its Eco-Toxicological Risk: Case of Nokoue Lake South Benin. International Journal of Biological and Chemical Sciences, 5, 1590-1602. http://dx.doi.org/10.4314/ijbcs.v5i4.23

[52] Dèdjiho, C.A., Mama, D., Tomètin, L., Nougbodé, I., Chouti, W., Sohounhloué, C.K.D. and Boukari, M. (2013) Physical and Chemical Quality Assessment of Some Wastewater Tributaries of Ahémé Lake in Benin. Journal of Applied Biosciences, 70, 5608-5616. http://dx.doi.org/10.4314/jab.v70i1.98763

[53] Zabbey, N. and Hart, A.I. (2014) Spatial Variability of Macrozoobenthic Diversity on Tidal Flats of the Niger Delta, Nigeria: The Role of Substratum. African Journal of Aquatic Science, 39, 67-76. http://dx.doi.org/10.2989/16085914.2013.869657

[54] Sondergaard, M., Jensen, L.P. and Jeppensen, E. (2003) Role of Sediment and Internal Loading of Phosphorus in Shallow Lakes. Hydrobiologia, 506, 135-145. http://dx.doi.org/10.1023/B:HYDR.0000008611.12704.dd

[55] Sellami, I., Romdahane, S.B., Guermazi, W., El-Bour, M., Hamza, A., Mhamdi, M.A., Pinel-Alloul, B., Aleya, L. and Ayadi, H. (2012) Seasonal Dynamics of Plankton Communities Coupled with Environmental Factors in a Semi-Arid Area: Sidi Saâd Reservoir (Centre of Tunisia). African Journal of Biotechnology, 11, 865-877. http://dx.doi.org/10.5897/AJB11.2145

[56] Dahl, J., Johnson, R.K. and Sandin, L. (2004) Detection of Organic Pollution of Streams in Southern Sweden Using Benthic Macroinvertebrates. Hydrobiologia, 516, 161-172. http://dx.doi.org/10.1023/B:HYDR.0000025264.35531.cb

[57] Bode, R.W., Novak, M.A., Abele, L.E., Heitzman, D.L. and Smith, A.J. (2002) Quality Assurance Work Plan for Biological Stream Monitoring in New York State. Stream Biomonitoring Unit Bureau of Water Assessment and Management Division of Water, NYS Department of Environmental Conservation, Albany.

[58] Beneberu, G., Mengistou, S., Eggermont, H. and Verschuren, D. (2014) Chironomid Distribution along a Pollution Gradient in Ethiopian Rivers, and Their Potential for Biological Water Quality Monitoring. African Journal of Aquatic Science, 39, 45-56. http://dx.doi.org/10.2989/16085914.2013.870525

[59] Imoobe, T.O.T. and Ohiozebau, E. (2010) Pollution Status of a Tropical Forest River Using Aquatic Insects as Indicators. African Journal of Ecology, 48, 232-238. http://dx.doi.org/10.1111/j.1365-2028.2009.01153.x 